\title{
In vitro dissolution kinetic for mycophenolic acid derivatives tablets
}

\author{
André Lima de Oliveira Costa ${ }^{1, *}$, Paula Cristina Rezende Enéas ${ }^{1}$, Tiago Assis Miranda ${ }^{1}$, \\ Sueli Aparecida Mingoti ${ }^{2}$, Cristina Duarte Vianna Soares ${ }^{1}$, Gerson Antônio Pianetti ${ }^{1}$
}

\author{
${ }^{1}$ Departament of Pharmaceutical Products, Faculty of Pharmacy, ${ }^{2}$ Departament of Statistics, Institute of Exact Sciences, \\ Federal University of Minas Gerais
}

\begin{abstract}
Mycophenolate mofetil (MMF) and mycophenolate sodium (MPS) are an ester and a salt of mycophenolic acid. They have different kinetic in vivo characteristics due to differences in molecular structures, physicochemical properties and formulations administered. In this study, dissolution profiles of reference products were tested in different media to evaluate the effect of $\mathrm{pH}$, kinetic dissolution and the best statistical model that can be used to predict the release of both drugs. The drug release was determined by using a validated ultraviolet spectrophotometry method, $\lambda 250 \mathrm{~nm}$. The method showed to be selective, linear, precise and accurate for MMF in $0.1 \mathrm{M} \mathrm{HCl}$ and MPS in sodium phosphate buffer pH 6.8. Dissolution kinetics models of zero order, first order, Higuchi, Hixson-Crowell and Weibull were applied to data in order to select the best fit by linear regression. The regression parameters were estimated and the models were evaluated with the results of residuals and coefficient of determination. The residuals obtained from dissolution kinetics models were random, uncorrelated, and normally distributed with constant variance. The $R^{2}$ values (74.7\% for MMF and $95.8 \%$ for MPS) demonstrated good ability of the Weibull regression to explain the variability and to predict the drugs' release.
\end{abstract}

Uniterms: Mycophenolate sodium. Mycophenolate mofetil. Dissolution profiles. Weibull kinetics.

\begin{abstract}
Micofenolato de mofetila (MMF) e micofenolato sódico (MPS) são, respectivamente, éster e sal sódico do ácido micofenólico. Os fármacos possuem características farmacocinéticas distintas em função das diferenças na estrutura molecular, nas propriedades físico-químicas e nas formulações administradas. Neste trabalho, os perfis de dissolução dos medicamentos referências foram testados em diferentes meios de dissolução com o objetivo de avaliar o efeito da variação de $\mathrm{pH}$, a cinética de dissolução e o modelo estatístico mais adequado para prever a dissolução dos fármacos. A liberação dos fármacos foi determinada com método validado por espectroscopia no ultravioleta, $\lambda 250 \mathrm{~nm}$. O método mostrou-se seletivo, linear, preciso e exato para dissolução de MMF em 0,1 M HCl e MPS em tampão fosfato pH 6,8. Os modelos cinéticos de dissolução de ordem zero, primeira ordem, Higuchi, Hixson-Crowell e Weibull foram aplicados com o objetivo de selecionar aquele com o melhor ajuste por regressão linear. Os parâmetros de regressão foram estimados e os ajustes dos modelos foram verificados pelos resíduos e coeficientes de determinação. Os resíduos obtidos foram aleatórios, independentes, apresentaram variância constante e seguiram a distribuição normal. Os valores de $R^{2}(74,7 \%$ para MMF e 95,8\% para MPS) indicaram bom ajuste da regressão de Weibull para explicar a variabilidade e estimar a liberação dos fármacos.
\end{abstract}

Unitermos: Micofenolato sódico. Micofenolato de mofetila. Perfil de dissolução. Cinética de Weibull.

\section{INTRODUCTION}

Mycophenolic acid (MPA), commonly used in the immunosuppressive therapy of post-transplant patients,

*Correspondence: A.L.O. Costa. Departamento de Produtos Farmacêuticos, Faculdade de Farmácia, Universidade Federal de Minas Gerais, 31.270-901 Belo Horizonte - MG, Brasil. E-mail: sodioepotassio@hotmail.com is a specific, non-competitive and reversible inhibitor of inosine monophosphate dehydrogenase (Noronha et al., 2005; Sánchez-Fructuoso, 2005; Staatz, Tett, 2007). It is administered as a pro-drug, the ester mycophenolate mofetil (MMF), or its salt, mycophenolate sodium (MPS) (Figure 1).

Following oral administration, MMF undergoes rapid and extensive absorption and complete pre-systemic 
<smiles>COc1c(C)c2c(c(O)c1C/C=C(\C)CCC(=O)O)C(=O)OC2</smiles><smiles>COc1c(C)c2c(c(O)c1C/C=C(\C)CCC(=O)OCCN1CCOCC1)C(=O)OC2</smiles><smiles>COc1c(C)c2c(c(O)c1C/C=C(\C)CCC(=O)O[Na])C(=O)OC2</smiles>

FIGURE 1 - Chemical structures of (a) mycophenolic acid, (b) mycophenolate mofetil and (c) mycophenolate sodium.

metabolism to MPA. The active metabolite reaches maximum plasma concentration after $1 \mathrm{~h}$ and a secondary increase in plasma is observed at approximately 6-12 h post dose (Staatz, Tett, 2007; Lee et al., 1990; Jeong, Kaplan, 2007).

Enteric-coated mycophenolate sodium (EC-MPS) was developed to reduce the incidence and severity of gastric side effects of mycophenolate mofetil immediate release tablets (MMF-IR) used in immunosuppressive therapy. The goal of this formulation development was delaying release and absorption of MPA to reduce the incidence of gastrointestinal effects (Arns, 2007; Budde et al., 2004; Sábada et al., 2005). After oral administration of EC-MPS the absolute bioavailability is greater than $71 \%$ and peak plasma concentration is reached within 1.5 to $2 \mathrm{~h}$ (Sánchez-Fructuoso, 2005; Zolezzi, 2005).

Several analytical methods for MPA have been established to support pharmacokinetics studies of ECMPS compared with MMF-IR in human and animal models (Tsina et al., 1996; Barkosi, 2005; Wiwattanawongsa, 2001). The drugs demonstrated similar efficacy and safety profile, indicating that patients receiving MMF-IR as maintenance therapy can be safely interchanged to ECMPS. However, there is no consensus on reducing the adverse effects (Sánchez-Fructuoso, 2005; Arns, 2007; Budde et al., 2004; Sábada et al., 2005; Zolezzi, 2005).
Despite similar safety and efficacy, the tablets may present different drug releases after oral administration. The objectives of this work were evaluated dissolution profiles of MMF-IR and EC-MPS in different media to determine the $\mathrm{pH}$ effect on drug release and applied statistical models to describe the dissolution kinetics.

\section{MATERIAL AND METHODS}

\section{Reagents and chemicals}

MPA from Sigma-Aldrich ${ }^{\circledR}$ (St. Louis, MO, USA, batch 097K4005) and MMF reference standard from European Pharmacopoeia, batch 2.0, were obtained. The reference tablets CellCept ${ }^{\circledR} 500 \mathrm{mg}$ (MMF-IR, Roche) and Myfortic ${ }^{\circledR} 360 \mathrm{mg}$ (EC-MPS, Novartis) were used. The analytical reagents concentrated hydrochloric acid, methanol, sodium monobasic phosphate and sodium tribasic phosphate were purchased (J.T. Baker ${ }^{\circledR}$, Phillipsburg, NJ, USA). High purity water was used (Milli-Q, Millipore $^{\circledR}$, Bedford, MA, USA).

\section{Instrumentation and analytical conditions}

The dissolution profiles were performed in a dissolution system (Erweka ${ }^{\circledR}$ DT 80) in accordance to specifications of The United States Pharmacopeia (USP 34, 2011). The drug release percentage was determined in a UV-Vis spectrophotometer (HP8453, Agilent, Palo Alto, CA, USA) at $\lambda 250 \mathrm{~nm}$, in adequate diluents.

\section{Dissolution profiles}

Immediate release profile of MMF was carried out using six units in each medium: $0.1 \mathrm{M} \mathrm{HCl}, 0.01 \mathrm{M}$ $\mathrm{HCl}$ and $0.1 \mathrm{M}$ sodium phosphate buffer (PBS) $\mathrm{pH} 3.0$ maintained at $37 \pm 0.5^{\circ} \mathrm{C}$. Paddle apparatus were used at $50 \mathrm{rpm}$ and dissolution points were defined at 5, 10, 15, 30,45 and $60 \mathrm{~min}$. The samples were filtered through a $0.45 \mu \mathrm{m}$ membrane and exactly diluted to approximately $25 \mu \mathrm{g} / \mathrm{mL}$. The amount of MMF dissolved was determined against MMF standard solution in dissolution medium at same concentration.

Dissolution profiles for EC-MPS tablets were obtained according to USP general method $<711>$ for dissolution of enteric-coated tablets. The dissolution started with $750 \mathrm{~mL} 0.1 \mathrm{M} \mathrm{HCl}$ at $37 \pm 0.5^{\circ} \mathrm{C}$ and paddle apparatus at $50 \mathrm{rpm}$. After $120 \mathrm{~min}$, an aliquot was collected and $250 \mathrm{~mL}$ of $0.20 \mathrm{M}$ sodium phosphate buffer tribasic, $37 \pm 0.5^{\circ} \mathrm{C}$, were added. The $\mathrm{pH}$ of each vessel was rapidly adjusted to $6.8 \pm 0.05$. The amount of MPS dissolved 
was determined after 10,20, 30, 45, 60, 90 e $120 \mathrm{~min}$ in buffer medium. A stock solution of MPA standard was prepared in methanol at $450 \mu \mathrm{g} / \mathrm{mL}$ and diluted in dissolution media to final concentration of $18 \mu \mathrm{g} / \mathrm{mL}$. The same procedure was performed to obtain dissolution profiles at adjusted $\mathrm{pH}$ values of $6.0 \pm 0.05$ and $5.5 \pm 0.05$.

Statistical comparison was performed by Duncan test at $95 \%$ of confidence for the selection of an ideal medium and, dissolution test specifications were proposed for each drug. The difference of average drug release at each time point was considered significantly if it was larger than the critical value. Similarity factor $\left(f_{2}\right)$ was also determined to compare the curves of dissolution. In Equation 1 for $f_{2}$ factor $n$ is the number of dissolution points, Rt and $T_{t}$ are the reference and test dissolution values at time $t$. Values of $f_{2}$ between 50 and 100 ensure the sameness of two dissolution profiles (USA, 1997).

$f_{2}=50 \log \left\{\left[1+\frac{1}{n} \Sigma_{t=1}^{n}\left(\mathrm{R}_{\mathrm{t}}-\mathrm{T}_{\mathrm{t}}\right)^{2}\right]^{-0.5} \times 100\right\}$ Eq. 1

\section{Dissolution kinetics}

Mathematical models are often used to describe dissolution profiles and to compare drug release by dependent method. The evaluation of dissolution kinetics allows knowing the rate of the process, the maximum concentration dissolved and when significant, changes occur (Patel et al., 2008; Raslan, Maswadeh, 2006; Demirturk, Oner, 2005; Serra, Storpirtis, 2007).

The release kinetics of MMF-IR tablets in $0.1 \mathrm{M}$ $\mathrm{HCl}$ and EC-MPS in PBS pH 6.8 were analyzed by linear regression using different mathematical models (see Table I). The general function of a simple linear regression is described by Equation 2, where $\beta_{0}$ is the intercept, $\beta_{l}$ is the slope and $\varepsilon$ the random error (residual) with zero mean and variance $\sigma^{2}$.

$$
\mathrm{f}_{(\mathrm{xi})}=\beta_{0}+\beta_{l} \mathrm{x}_{\mathrm{i}}+\varepsilon_{i} \quad \text { Eq. } 2
$$

Regression parameters $\left(\beta_{0}\right.$ and $\left.\beta_{l}\right)$ were estimated by least squares method and the best fit model was selected for each drug based on the results of the coefficient of determination $\left(R^{2}\right)$ and residual analyses. The observations at 5, 10, 15 and $30 \mathrm{~min}$ were used for MMF-IR. The kinetics studied for EC-MPS were assessed in the time interval 10-45 min in the buffered stage.

Pharmaceutical dosage forms that follow zero order kinetics, release the same amount of drug per unit of time. In the first order kinetics, the plot of dissolution time versus natural logarithm of the percentage dissolved drug was evaluated. Drug release occurs proportionally to the drug amount remaining inside the dosage form, so that the amount of drug released per unit time decreases (Manadas et al., 2002).

Higuchi developed several theoretical models to study the release of soluble and poorly soluble drugs incorporated in solid and semi-solid matrices. The simplified Higuchi model is based on Fick's law of diffusion and the square root of time is described versus drug release (Manadas et al., 2002). The equation of the Hixson-Crowell model considers the principle that the area of a particle is proportional to the cube root of its volume. This model assumes that the release rate is limited by the dissolution of the particles of the drug and not by diffusion in the matrix tablet.

The general empirical equation described by Weibull (Equation 3) was applied to the drug release processes and provides satisfactory results for almost all types of dissolution curves.

$$
\log [-\ln (1-m)]=\beta \log \left(t-T_{i}\right)-\log \alpha \quad \text { Eq. } 3
$$

In Weibull model, the statistical parameter $\alpha$ defines the time scale of the process estimated from $\mathrm{X}$ value $(\mathrm{t}=1)$, $T_{i}$ represents the time interval before dissolution starts $\left(T_{i=0}\right)$ and $\beta$ is the shape parameter that characterizes the curve as exponential $(\beta=1)$, sigmoid $(\beta>1)$ or parabolic $(\beta<1)$.

TABLE I - Regression models applied to dissolution profiles of MMF-IR and EC-MPS tablets

\begin{tabular}{lccc}
\hline Model & Equation & $\beta_{0}$ & $\beta_{1}$ \\
\hline Zero order & $Q_{t}=Q_{0}+k_{0} t$ & $Q_{0}$ & $k_{0}$ \\
First order & $\ln Q_{t}=\ln Q_{0}+k_{1} t$ & $\ln Q_{0}$ & $k_{1}$ \\
Higuchi & $Q_{t}=Q_{0}+k_{\mathrm{H}} t^{1 / 2}$ & $Q_{0}$ & $k_{H}$ \\
Hixson-Crowell & $Q_{0}{ }^{1 / 3}-Q_{\mathrm{t}}{ }^{1 / 3}=k_{w} t$ & $Q_{0}{ }^{1 / 3}$ & $k_{W}$ \\
Weibull & $\log [-\ln (1-m)]=\beta \log \left(t-T_{i}\right)-\log \alpha$ & $-\log \alpha$ & $\beta$ \\
\hline
\end{tabular}

$Q_{t}$ : amount of drug released in time $t ; Q_{0}$ : initial amount of drug in dissolution media; $k_{0}, k_{1}, k_{H}, k_{W}:$ release rate constants; $m$ : accumulated fraction of the drug; $\alpha$ : scale parameter; $\beta$ : shape parameter; $T_{i}$ : location parameter. 
The Weibull linear relationship was obtained by log-log plot of time versus $-\ln (1-m)$, where $m$ is the cumulative fraction of drug dissolved over a time $t$ (Manadas et al., 2002; Yukse et al., 2000).

\section{Method validation}

Spectrophotometric method was validated regarding merit figures specificity, linearity, accuracy, precision, detection (LOD) and quantitation limits (LOQ) for MMF-IR in $0.1 \mathrm{M} \mathrm{HCl}$ and, for EC-MPS in PBS pH 6.8 , according to $\mathrm{ICH}$ guidelines (ICH, 2005). EC-MPS determination was expressed in the equivalent amount of MPA.

Placebo enriched by standard solutions was used to evaluate selectivity over the range 200-400 $\mathrm{nm}$. MMF-IR placebo formulation contained microcrystalline cellulose, croscarmellose sodium, magnesium stearate, Povidone K-90, Hypromellose, titanium dioxide, indigo carmine and yellow iron oxide. EC-MPS placebo was composed by corn starch, Povidone K-90, Crospovidone, lactose, colloidal silicon dioxide, magnesium stearate, Hypromellose, titanium dioxide, indigotine, yellow iron oxide and red iron oxide.

Linearity was evaluated by thirty determinations across the range $5.0-50.0 \mu \mathrm{g} / \mathrm{mL}$ for MMF and by twenty four determinations across the range $6.0-34.0 \mu \mathrm{g} / \mathrm{mL}$ for MPA. The results were analyzed by visual inspection and a regression model estimated by the least squares method. Detection and quantitation limits were estimated based on the standard deviation of the intercept $\left(s_{a}\right)$ and the slope (b) of the respective analytical curve were used following Equations 4 and 5.

$$
\begin{aligned}
& L O D=3.3 s_{a} / b \\
& L O Q=10 s_{a} / b
\end{aligned}
$$

Eq. 4

Eq. 5

Precision was investigated in the tablets by repeatability (intra-day) and intermediate precision (inter-day) using six determinations in three different days. Final test concentrations were $25 \mu \mathrm{g} / \mathrm{mL}$ for MMF and $18 \mu \mathrm{g} / \mathrm{mL}$ for MPA. Intra-day precision was reported as relative standard deviation (RSD) and inter-day precision was evaluated by comparison of the means in different days, by Anova $(\alpha=0.05)$.

In order to evaluate accuracy, three placebo samples were added of different standard concentrations of $\operatorname{MMF}(17.5,25.0,32.5 \mu \mathrm{g} / \mathrm{mL})$ and of MPA $(12.6,18.0$, $23.4 \mu \mathrm{g} / \mathrm{mL})$. Recovery was expressed by the ratio of experimental to nominal drug percentage concentrations.

\section{RESULTS}

\section{Dissolution profiles}

The MMF-IR dissolution profiles shown in Figure 2a were statistically different at all sampling times $(p<0.05)$. It was observed that the amount of MMF released in PBS pH 3.0 was significantly different to that released in $0.1 \mathrm{M} \mathrm{HCl}(p<0.05)$ at all points. The dissolution profile in $0.01 \mathrm{M} \mathrm{HCl}$ was not significantly different to that in PBS pH 3.0 at initial points $(p>0.05)$. However, the dissolution curves in media $0.01 \mathrm{M} \mathrm{HCl}$ and $0.1 \mathrm{M} \mathrm{HCl}$ yield superposed points, starting at $30 \mathrm{~min}$, in the plateau region (see Table II).

The similarity factor was applied to compare the dissolution profile over 0-30 min (critical interval of dissolution). In a similar drug dissolution was observed the curves in $0.1 \mathrm{M} \mathrm{HCl}$ vs. $0.01 \mathrm{M} \mathrm{HCl}\left(f_{2}=53.15\right)$, as well as for those in $0.01 \mathrm{M} \mathrm{HCl}$ vs. PBS pH 3.0 media $\left(f_{2}=70.37\right)$. However, the curves were considered statistically different
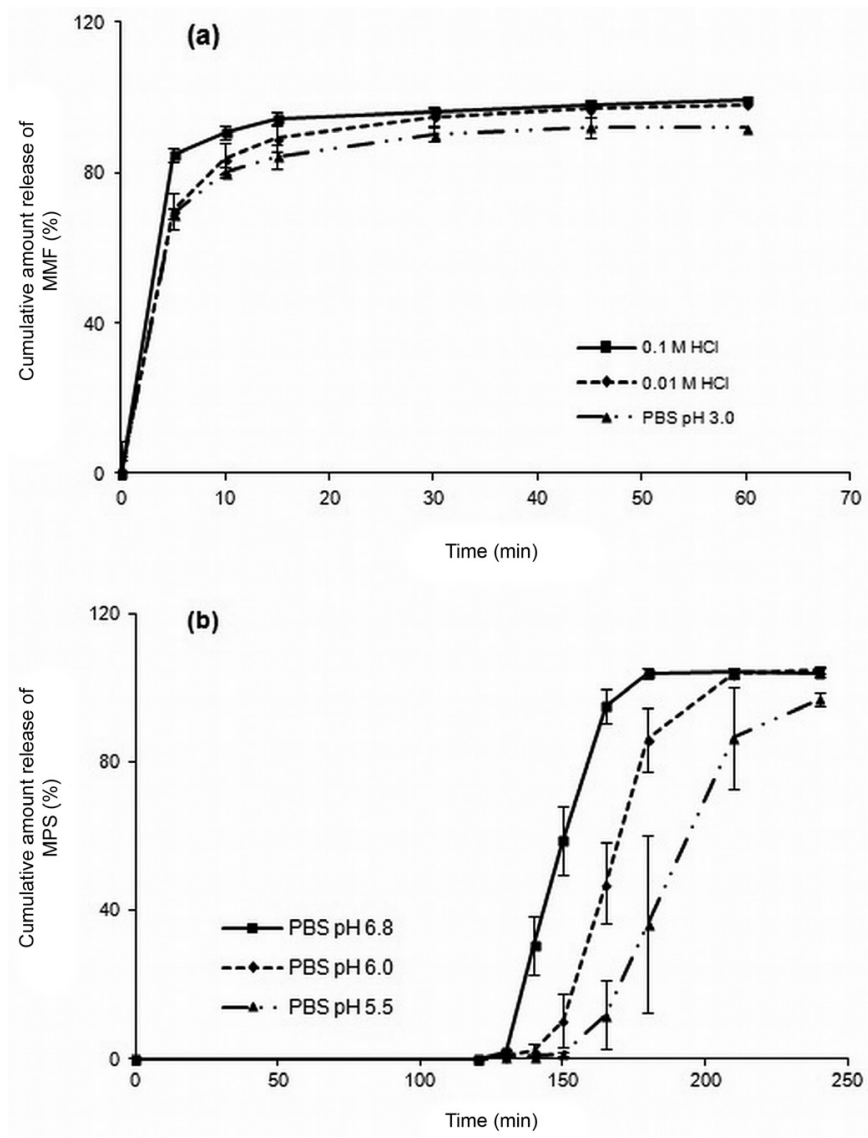

FIGURE 2 - Cumulative amount release for (a) MMF-IR in 0.1 $\mathrm{M} \mathrm{HCl}, 0.01 \mathrm{M} \mathrm{HCl}$ and PBS pH 3.0 and for (b) EC-MPS in PBS pH 5.5, 6.0 and 6.8 at $37 \pm 0.5^{\circ} \mathrm{C}$, paddles, $50 \mathrm{rpm}$, using UV method, $\lambda 250 \mathrm{~nm}$. 
between the tested media $0.1 \mathrm{M} \mathrm{HCl}$ vs. PBS pH 3.0 $\left(f_{2}=47.75\right)$. Despite the difference of drug dissolution found in $0.1 \mathrm{M} \mathrm{HCl}, 0.01 \mathrm{M} \mathrm{HCl}$ and PBS pH 3.0 media, the cumulative amount $(94.44 \%, 89.07 \%$ and $84.33 \%$, respectively) was greater than $80 \%$ in all media in the time point $15 \mathrm{~min}$.

Figure $2 \mathrm{~b}$ depicts the EC-MPS tablets dissolution profile. The first stage release was performed during $120 \mathrm{~min}$ in $0.1 \mathrm{M} \mathrm{HCl}$ with the aim to evaluate the resistance of the enteric coating. In the second stage, the aim was to characterize the delayed release profile during $120 \mathrm{~min}$ in the media PBS pH 5.5, 6.0 and 6.8. The tablets remained visually intact in the acid stage and the amount of drug released was negligible $(0.0 \%)$. Moreover, there was a greater drug release with the increase of $\mathrm{pH}$. The dissolution steady state was first achieved within $60 \mathrm{~min}$ in PBS pH 6.8. EC-MPS dissolution profile was significantly different in the media at all sampling times $(p<0.05)$. Duncan test showed that the amounts of MPS dissolved in PBS pH 6.8 were significantly different when compared to those in PBS pH 5.5. The drug dissolution profile in PBS $\mathrm{pH} 6.0$ was similar to that in PBS pH 5.5 at the two initial points and closer to that in PBS pH 6.8 at the final three dissolution points (Table III).

By using the similarity factor approach over the first $45 \mathrm{~min}$ for the second stage of the dissolution profile of EC-MPS tablets, $f_{2}$ values were smaller than 50 and pointed for no similarity observed between the curves $\left(f_{2}=21.71\right.$ for $\mathrm{pH} 6.8$ vs. $6.0 ; f_{2}=13.93$ for $\mathrm{pH} 6.8$ vs. 5.5; $f_{2}=36.87$ for $\mathrm{pH} 6.0$ vs. 5.5). Hence, the $\mathrm{pH}$ was critical for the drug dissolution profile at this stage.

\section{Dissolution kinetics}

Dissolution kinetics was studied considered the dissolution profiles of MMF-IR and EC-MPS in $0.1 \mathrm{M}$ $\mathrm{HCl}$ and $\mathrm{PBS} \mathrm{pH}$ 6.8, respectively. The mathematical models for zero order, first order, Higuchi, HixonCrowel and Weibull were applied to determine the best model to represent the dissolution process. Results of $R^{2}$ (coefficient of determination), intercept $\left(\beta_{0}\right)$ and slope $\left(\beta_{l}\right)$, normality test for standardized residual and significance of parameters were evaluated for MMF-IR and EC-MPS, according to Tables IV and V.

\section{Method validation}

Interference of placebo was not observed over the range $200-400 \mathrm{~nm}$, attesting for the method selectivity. The calibration curves showed linearity over the ranges 5.0-50.0 $\mu \mathrm{g} / \mathrm{mL}$ for MMF and 6.0-34.0 $\mu \mathrm{g} / \mathrm{mL}$ for MPA determinations. The regressions were significant $(p<0.05)$ and data showed good curve fits. All $R^{2}$ values were greater than $99.9 \%$, which is the proportion explained by the

TABLE II - Duncan test $(\alpha=0.05)$ for MMF-IR dissolution profiles in the media $0.1 \mathrm{M} \mathrm{HCl}, 0.01 \mathrm{M} \mathrm{HCl}$ and PBS pH $3.0 \mathrm{using} \mathrm{UV}$ method, $\lambda 250 \mathrm{~nm}$

\begin{tabular}{lcccccc}
\hline \multirow{2}{*}{ Dissolution media } & \multicolumn{7}{c}{ Time (min) } \\
\cline { 2 - 7 } & 5 & 10 & 15 & 30 & 45 & 60 \\
\hline $0.1 \mathrm{M} \mathrm{HCl}$ vs. PBS pH 3.0 & 15.45 & 10.52 & 10.11 & 6.01 & 5.95 & 7.24 \\
$0.1 \mathrm{M} \mathrm{HCl}$ vs. 0.01 M HCl & 14.63 & 7.12 & 5.37 & $1.26^{*}$ & $1.10^{*}$ & $1.23^{*}$ \\
$0.01 \mathrm{M} \mathrm{HCl}$ vs. PBS pH 3.0 & $0.82^{*}$ & $3.40^{*}$ & 4.74 & 4.75 & 4.85 & 6.01 \\
Critical value & 7.56 & 3.91 & 3.53 & 3.75 & 2.37 & 2.73 \\
\hline
\end{tabular}

*No significant difference.

TABLE III - Duncan test $(\alpha=0.05)$ for EC-MPS dissolution profiles in media PBS pH 5.5, 6.0 and 6.8, using UV method, $\lambda 250$ nm

\begin{tabular}{lccccccc}
\hline \multirow{2}{*}{ Dissolution media } & \multicolumn{7}{c}{ Time (min) } \\
\cline { 2 - 8 } & 10 & 20 & 30 & 45 & 60 & 90 & 120 \\
\hline PBS pH 6.8 vs. PBS pH 5.5 & 1.19 & 29.83 & 57.32 & 83.08 & 67.55 & 17.58 & 7.03 \\
PBS pH 6.8 vs. PBS pH 6.0 & 1.01 & 28.32 & 48.35 & 47.68 & $17.79^{*}$ & $0.44^{*}$ & $0.95^{*}$ \\
PBS pH 6.0 vs. PBS pH 5.5 & $0.18^{*}$ & $1.51^{*}$ & 8.97 & 35.40 & 49.76 & 17.14 & 7.98 \\
Critical value & 0.37 & 6.30 & 8.67 & 11.16 & 18.84 & 10.20 & 1.83 \\
\hline
\end{tabular}

*No significant difference. 
TABLE IV - Results of the regression fit models for MMF-IR dissolution profile in selected medium $0.1 \mathrm{M} \mathrm{HCl}$, using UV method, $\lambda 250 \mathrm{~nm}$

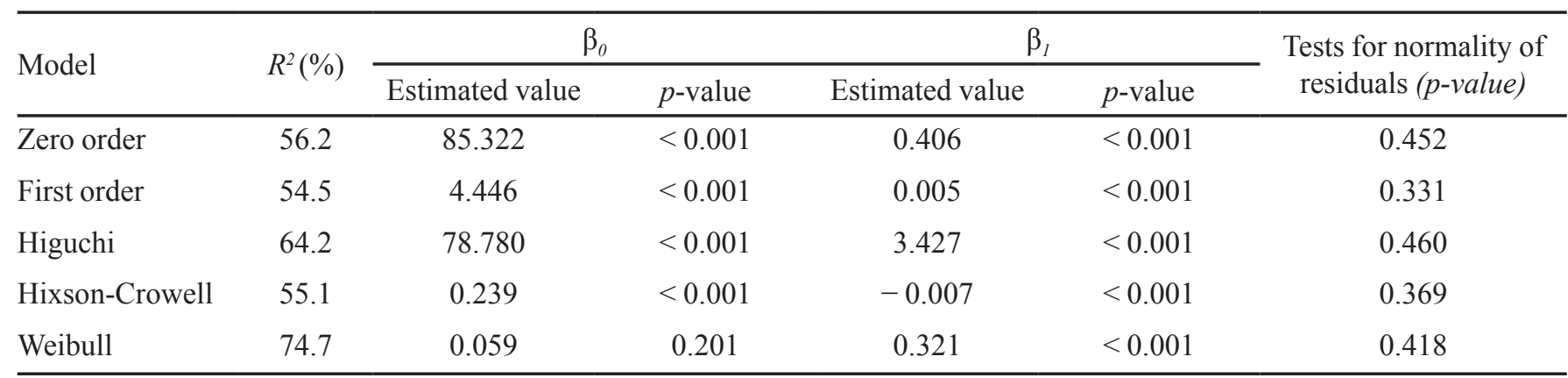

TABLE V - Results of the regression fit models for EC-MPS dissolution profile in selected medium PBS pH 6.8, using UV method, $\lambda 250 \mathrm{~nm}$

\begin{tabular}{|c|c|c|c|c|c|c|}
\hline Model & $R^{2}(\%)$ & \multicolumn{2}{|c|}{$\beta_{0}$} & \multicolumn{2}{|c|}{$\beta_{1}$} & $\begin{array}{l}\text { Tests for normality of } \\
\text { residuals ( } p \text {-value) }\end{array}$ \\
\hline Zero order & 97.0 & -23.163 & $<0.001$ & 2.654 & $<0.001$ & 0.016 \\
\hline First order & 76.2 & 0.405 & 0.278 & 0.104 & $<0.001$ & $<0.005$ \\
\hline Higuchi & 96.7 & -83.813 & $<0.001$ & 26.302 & $<0.001$ & 0.120 \\
\hline Weibull & 95.8 & -5.118 & $<0.001$ & 3.457 & $<0.001$ & 0.059 \\
\hline
\end{tabular}

total variance of the response by the regression models (Table VI). The LOD and LOQ limits were calculated from the response standard deviation of the intercept and the slope of the analytic regression line. Estimated LOD value for MMF was $0.32 \mu \mathrm{g} / \mathrm{mL}$ and $0.13 \mu \mathrm{g} / \mathrm{mL}$ for MPA. The estimated LOQ values were $0.97 \mu \mathrm{g} / \mathrm{mL}$ for MMF and $0.45 \mu \mathrm{g} / \mathrm{mL}$ for MPA.

The Table VII shows the precision and accuracy results. Precision was calculated by MMF and MPA determinations in tablets in three days. All RSD values were lower than $2.0 \%$ and there was no significant difference between averages in the three-day analyses $(p>0.05)$.
Accuracy, investigated by standard recovery over three different concentrations, resulted in experimental values near the nominal concentrations. Recovery means were $99.28 \%$ for MMF and $99.84 \%$ for EC-MPS.

\section{DISCUSSION}

The dissolution media used was defined based on the best solubility and characteristics of the drug formulations. MMF is formulated as immediate release tablets, nevertheless, the drug is poorly soluble in water. Hence, an increase in hydrogen ion concentration of the

TABLE VI - Results of linearity, LOD and LOQ for MMF and MPA in selected media $0.1 \mathrm{M} \mathrm{HCl}$ and PBS pH 6.8, respectively, using UV method, $\lambda 250 \mathrm{~nm}$

\begin{tabular}{lcc}
\hline Coefficients & MMF in 0.1 M HCl & MPA in PBS pH 6.8 \\
\hline$R^{2}(\%)$ & 99.98 & 99.99 \\
Slope \pm standard deviation & $0.0203 \pm 0.0001$ & $0.0292 \pm 0.0001$ \\
Intercept \pm standard deviation & $0.0030 \pm 0.0020$ & $0.0003 \pm 0.0013$ \\
LOD $(\mu \mathrm{g} / \mathrm{mL})$ & 0.32 & 0.13 \\
LOQ $(\mu \mathrm{g} / \mathrm{mL})$ & 0.97 & 0.45 \\
\hline
\end{tabular}


TABLE VII - Precision $(\mathrm{n}=18)$ and recovery $(\mathrm{n}=12)$ data for MMF-IR and EC-MPS tablets, in selected media $0.1 \mathrm{M} \mathrm{HCl}$ and PBS $\mathrm{pH} 6.8$, respectively, using UV method, $\lambda 250 \mathrm{~nm}$

\begin{tabular}{|c|c|c|c|c|c|}
\hline \multicolumn{3}{|c|}{ Precision for MMF-IR } & \multicolumn{3}{|c|}{ Precision for EC-MPS } \\
\hline Day & Mean $(\%)$ & RSD (\%) & Day & Mean (\%) & RSD (\%) \\
\hline 1 & 99.11 & 0.33 & 1 & 99.78 & 0.66 \\
\hline 2 & 99.88 & 0.90 & 2 & 99.94 & 1.30 \\
\hline 3 & 99.25 & 0.89 & 3 & 100.36 & 0.61 \\
\hline \multicolumn{3}{|c|}{ Recovery for MMF-IR } & \multicolumn{3}{|c|}{ Recovery for EC-MPS } \\
\hline $\begin{array}{l}\text { Standard added } \\
(\mu \mathrm{g} / \mathrm{mL})\end{array}$ & Mean $(\%)$ & RSD (\%) & $\begin{array}{c}\text { Standard added } \\
(\mu \mathrm{g} / \mathrm{mL})\end{array}$ & Mean $(\%)$ & $\operatorname{RSD}(\%)$ \\
\hline 17.5 & 99.83 & 0.37 & 12.6 & 100.79 & 0.39 \\
\hline 25.0 & 99.03 & 0.13 & 18.0 & 99.30 & 0.99 \\
\hline 32.5 & 98.97 & 0.34 & 23.4 & 99.42 & 0.17 \\
\hline
\end{tabular}

medium favors its solubility (Lee et al., 1990). Because of this feature, the acidic dissolution media $0.1 \mathrm{M} \mathrm{HCl}$, $0.01 \mathrm{M} \mathrm{HCl}$ and $0.1 \mathrm{M}$ PBS pH 3.0 were selected to determine the dissolution profile of MMF tablets.

The mean release at $15 \mathrm{~min}$ in $0.1 \mathrm{M} \mathrm{HCl}$ was almost complete (94.44\%) for MMF-IR. According to the regulatory agency Food and Drug Administration (USA, 1997), a drug product undergoing $85 \%$ dissolution in 15 min under mild dissolution test conditions behaves like a solution. Thus, generally, it should not have any bioavailability problems since the mean gastric emptying time $\left(\mathrm{t}_{50 \%}\right)$ is 15 to $20 \mathrm{~min}$ under fasting conditions. The use of $0.1 \mathrm{M} \mathrm{HCl}$ as the dissolution medium was appropriate for MMF-IR and the acceptance criteria, $Q=85 \%$, for a very fast dissolving release $(94.44 \%$, in $15 \mathrm{~min})$ can be applied as a quality control.

For EC-MPS, no drug release was detected at the acid stage. The MPS mean dissolution at $45 \mathrm{~min}$ of the buffered stage was $95.01 \%$ in $\mathrm{pH} 6.8,47.33 \%$ in $\mathrm{pH} 6.0$ and $11.93 \%$ in $\mathrm{pH}$ 5.5. The USP general method acceptance criteria for enteric-coated tablets consider the limit of $10 \%$ of the amount of drug dissolved in each unit after $120 \mathrm{~min}$ in 0.1 $\mathrm{M} \mathrm{HCl}$. A minimum of $80 \%$ of the dissolved amount for each unit after 45 min of dissolution is recommended at the buffered stage. These criteria are suitable for analysis of EC-MPS dissolution evaluation in PBS pH 6.8.

A regression model is well adjusted when the average of the response variable $\mathrm{Y}$ is a linear function of the predictor variable $X$, the variance of the residuals is constant, the residuals follow the normal distribution with zero mean and are independent. The value of $R^{2}$ represents the proportion of the total variability of the variable $Y$ that is explained by the variable $\mathrm{X}$. This index is widely used to classify a set of regression because it scales the ability of the predictor variable in determining the response variable. However, $R^{2}$ should not be used as an isolated parameter without the validation of the assumptions established for the residuals in order to fit the regression model.

The zero order model was not ideal for evaluating the kinetics release of the drugs. The model did not show good ability to explain the data variation for MMF-IR $\left(R^{2}=56.2 \%\right)$. The $R^{2}$ value was larger for EC-MPS $(97.0 \%)$ but the residuals were not random and did not follow the normal distribution $(p<0.05)$. The first order model had no advantage over the initial results compared to the zero order model.

Weibull transformation resulted in a significant $(p<0.001)$ and valid regression for MMF-IR dissolution profile (Figure $3 \mathrm{a}$ ). This model explained $74.7 \%$ of total variance of observations. The final regression model could be described by the Equation 6, where $m$ is the cumulative fraction of drug dissolved over a time $t$.

For EC-MPS study, Higuchi transformation resulted in residuals with best fit to normal distribution. Noteworthy, $\beta_{0}$ parameter was not significantly different from zero $(p>0.05)$ only in first order model. This result is ideal because the drug release at time zero is null. Despite the merits of first order and Higuchi models, the best fit was yet obtained with Weibull transformation. The residuals showed to be random with constant variance (Levene test $p=0.700$ ) only with Weibull model. Data transformation resulted in a significant regression $(p<0.001)$ and the model was able to explain $95.8 \%$ of the total data variation (Figure $3 b$ ). The regression could be described by Equation 7 .

$\log (-\ln (1-m))=0.05912+0.3210 \log t \quad$ Eq. 6

$\log (-\ln (1-m))=-5.118+3.457 \log t \quad$ Eq. 7 

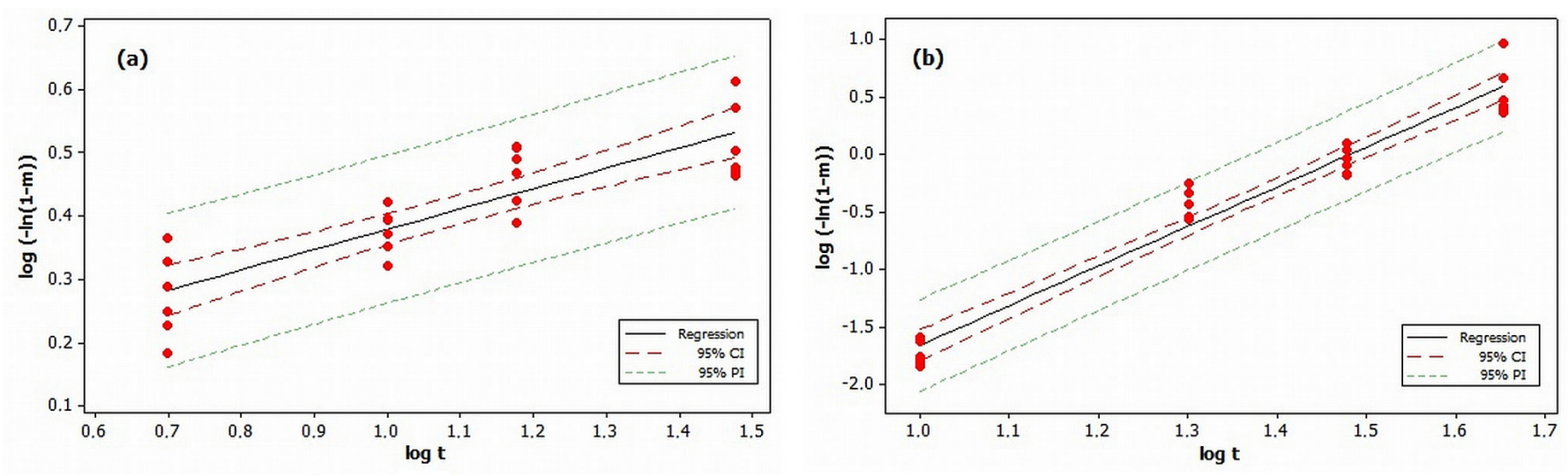

FIGURE 3 - Weibull regression for (a) MMF-IR and (b) EC-MPS profiles in selected media $0.1 \mathrm{M} \mathrm{HCl}$ and PBS pH 6.8, respectively, using UV method, $\lambda 250 \mathrm{~nm}$.

\section{CONCLUSIONS}

The results obtained for determination of mycophenolic acid derivatives after tablets dissolution by using UV spectrophotometry at $\lambda 250 \mathrm{~nm}$ showed to be selective, linear, precise and accurate. The use of $0.1 \mathrm{M} \mathrm{HCl}$ as a dissolution medium for MMF-IR was appropriate, considering dissolution acceptance criteria $\mathrm{Q}=85 \%$ of the labeled amount in $15 \mathrm{~min}$. A minimum criterion of $80 \%$ of the dissolved amount after $45 \mathrm{~min}$ is proposed for EC-MPS in PBS pH 6.8.

Weibull model showed a significant $(p<0.001)$ and best fit to linear regression for dissolution profile of MMF-IR and EC-MPS tablets. The obtained residuals were random, uncorrelated, and normally distributed with constant variance. The $R^{2}$ values $(74.7 \%$ for MMF-IR and $95.8 \%$ for EC-MPS) demonstrated good ability of the Weibull regression to explain the variability and to predict the drug release from the reference dosage forms.

\section{ACKNOWLEDGMENTS}

The authors thank the Brazilian Pharmacopoeia for financial support.

\section{REFERENCES}

ARNS, W. Noninfectious gastrointestinal (GI) complications of mycophenolic acid therapy: a consequence of local GI toxicity? Transplant. Proc., v.39, p.88-93, 2007.

BARKOZI, M.A.; ROUINI, M.; GHOLAMI, K.; PEZASHKI, M.L.; REZAEE, S. Determination of mycophenolic acid in human plasma by high-performace liquid chromatography. Daru, v.3, p.120-126, 2005.
BUDDE, K.; GLANDER, P.; DIEKMANN, F.; DRAGUN. D.; WAISER, J.; FRITSCHE, L.; NEUMAYER, H.H. Enteric-coated mycophenolate sodium: safe conversion from mycophenolate mofetila in maintenance renal transplant recipients. Transplant. Proc., v.36, p.524-527, 2004.

DEMIRTÜRK, E.; ÖNER, L. Evaluation of in vitro dissolution profile comparison methods of immediate release gliclazide tablets formulation. Hacettepe Univ. J. Pharm., v.25, p.110, 2005.

INTERNATIONAL CONFERENCE ON HARMONIZATION. ICH. Validation of analytical procedures: text and methodology (Q2 R1). London: ICH, 2005. 17 p.

JEONG, H; KAPLAN, B. Therapeutic monitoring of mycophenolate mofetil. Clin. J. Am. Soc. Nephrol., v.2, p.184-191, 2007.

LEE, W.A.; GU, L.; MIKSZTAL, A.R.; CHU, N.; LEUNG, K.; NELSON, P.H. Bioavailability improvement of mycophenolic acid through amino ester derivatization. Pharm. Res., v.7, p.161-166, 1990.

MANADAS, R.; PINA, M.E.; VEIGA, F. A dissolução in vitro na previsão da absorção oral de fármacos em formas farmacêuticas de liberação modificada. Rev. Bras, Cienc. Farm., v.38, p.375-399, 2002.

NORONHA, I.L.; OLIVEIRA, A.C.; ARAÚJO, M.R.T.; ABENSUR, H.; QUINTAES, S.L.; GENZINI, T.; PEDROSA, M.; CAMPAGNARI, M.M.; JÚNIOR, J.E.R. Micofenolato mofetil em transplante de órgãos. J. Bras. Nefrol., v.19, p.398-406, 2005. 
PATEL, N.; CHOTAI, N.; PATEL, J.; SONI, T.; DESAL, J.; PATEL, R. Comparison of in vitro dissolution profiles of oxcarbazepine-HP $\beta$-CD tablets formulations with marketed oxcarbazepine tablets. Dissol. Technol., v.15, p.28-34, 2008.

RASLAN, H.K.; MASWADEH, H. In vitro dissolution kinetic study of theophylline from mixed controlled release matrix tablets containing hydroxypropylmethyl cellulose and glycerylbehenate. Ind. J. Pharm. Sci., v.68, p.308-312, 2006.

SÁBADA, B.; AZANZA, J.R.; MUÑOZ, M.J.; GIL, I. Nuevas perspectivas del tratamiento inmunosupresor en el trasplante de órganos. Nefrologia, v.25, p.47-492, 2005.

SÁNCHEZ-FRUCTUOSO, A.I. Revisión de un nuevo inmunosupresor: micofenolato sódico con cubierta entérica $\left(\right.$ Myfortic $^{\circledR}$ ). Nefrologia, v.25, p.23-242, 2005.

SERRA, C.H.H.; STORPIRTIS, S. Comparação de perfis de dissolução da cefalexina através de estudos de cinética e eficiência de dissolução (ED\%). Rev. Bras. Ciênc. Farm., v.43, p.79-88, 2007.

STAATZ, C.E.; TETT, S.E. Clinical pharmacokinetics and pharmacodynamics of mycophenolate in solid organ transplant recipients. Clin. Pharm., v.46, p.13-58, 2007.

THE UNITED STATES PHARMACOPEIA. 34ed. Rockville: United States Pharmacopeial Convention, 2011. 4638 p.
TSINA, I.; KALOOSTIAN, M.; LEE, R.; TARNOWSKI, T.; WONG, B. High performance liquid chromatographic method for the determination of mycophenolate mofetil in human plasma. J. Chromatogr. B, v.681, p.347-353, 1996.

UNITED STATES OF AMERICA. Food and Drug Administration. Guidance for industry: dissolution testing of immediate release solid oral dosage forms. Silver Spring: Center for Drug Evaluation and Research, 1997. 17 p.

WIWATTANAWONGSA, K.; HEINZEN, E.L.; KEMPP, D.C.; DUPUIS, R.E.; SMITH, P.C. Determination of mycophenolic acid and its phenol glucuronide metabolite inhuman plasma and high-performance liquid. $J$. Chromatogr. B, v.763, p.35-45, 2001.

YUKSE, N.; KANIK, A.E.; BAYKARA, T. Comparison of in vitro dissolution profiles by Anova-based, model-dependent and-independent methods. Int. J. Pharm., v.209, p.57-67, 2000 .

ZOLEZZI, M. Mycophenolate sodium versus mycophenolate mofetil: a review of their comparative features. Saudi. J. Kidney Dis. Transplant., v.16, p.140-145, 2005.

Received for publication on $27^{\text {th }}$ August 2012 Accepted for publication on $21^{\text {st }}$ February 2013 